\title{
Az Országos Betétbiztosítási Alap kártalanítási tapasztalatai a betétesek korösszetételéről és a betétösszegek eloszlásáról*
}

\author{
Kallóné Csaba Katalin - Vajai Balázs
}

Magyarországon két év alatt (2014 és 2015) tíz hitelintézet került felszámolásra; a betéteseket az Országos Betétbiztosítási Alap kártalanította, összesen 219 Mrd forinttal. A felszámolt hitelintézetek betéteseinek adatbázisa első alkalommal kerül kutatásra. A kártalanítási adatokat leiró statisztikai eszközökkel jellemezzük a kifizetett kártalanítási összegek, valamint a betétesek életkorának dimenzióiban. Igazoljuk azt a hipotézist, miszerint a kifizetett kártalanitási összegek extrémérték-eloszlást, azon belül is Weibull-eloszlást követnek. Az eloszlás azt mutatja, hogy 5 millió forint felett a kártalanított betétesek száma csak kismértékben, míg a kifizetett kártalanitások összege jelentősen nőtt. A kártalanított betétesek korév szerinti megoszlását a magyar népesség korév szerinti megoszlásához viszonyítva pedig arra a megállapitásra jutunk, hogy a felszámolt hitelintézetekben elhelyezett megtakarítások Modigliani életciklus-elméletéhez igazodnak.

Journal of Economic Literature (JEL) kódok: D14, D18, G21

Kulcsszavak: lakossági megtakarítások/pénzügyek, fogyasztóvédelem, bankok

\section{Bevezetés és motiváció}

A magyar háztartási szektor 2015-ben pénzügyi eszközeinek megközelítőleg 20 százalékát ( 9 ezer Mrd Ft) bankbetétben és bank által kibocsátott kötvényben tartotta (Boldizsár - Koroknai 2016). A bankok finanszírozására fordított jelentős volumen a betétbiztosítást kiemelt szerephez juttatja a bankrendszerbe vetett bizalom kiépítésének és megtartásának kérdésében. A betétbiztosítási rendszer léte a bankrendszerbe vetett bizalom erősítésén keresztül a pénzügyi rendszer stabilitásának záloga. A magyar betétbiztosítási rendszert jelenleg a hitelintézetekről és a pénzügyi vállalkozásokról szóló 2013. évi CCXXXVII. törvény (Hpt.) felhatalmazása alapján az

* Jelen cikk a szerző nézeteit tartalmazza, és nem feltétlenül tükrözi a Magyar Nemzeti Bank hivatalos álláspontját.

Kallóné Csaba Katalin a Budapesti Corvinus Egyetem PhD-jelöltje. E-mail: csaba.katalin.corvinus@gmail.com. Vajai Balázs az Országos Betétbiztosítási Alap kockázatkezelési vezetője. E-mail: vajaib@oba.hu.

Jelen cikk a szerzők nézeteit tartalmazza, és nem feltétlenül tükrözi az Országos Betétbiztosítási Alap hivatalos álláspontját.

A kézirat első változata 2016. december 19-én érkezett szerkesztőségünkbe.

DOI: http://doi.org/10.25201/HSZ.16.2.2839 
Országos Betétbiztosítási Alap (OBA) múködteti. Ha egy hitelintézet fizetésképtelensége miatt az ott lévő bankbetét nem vehető fel, akkor az OBA húsz munkanapon belül - a kártalanításra jogosult magán- és jogi személyek részére egyaránt - kártalanítást fizet. A kártalanítás betétesenként és egy hitelintézetre összevontan 2011től legfeljebb 100 ezer eurónak megfelelő forintösszeg, korábban 50 ezer eurónak

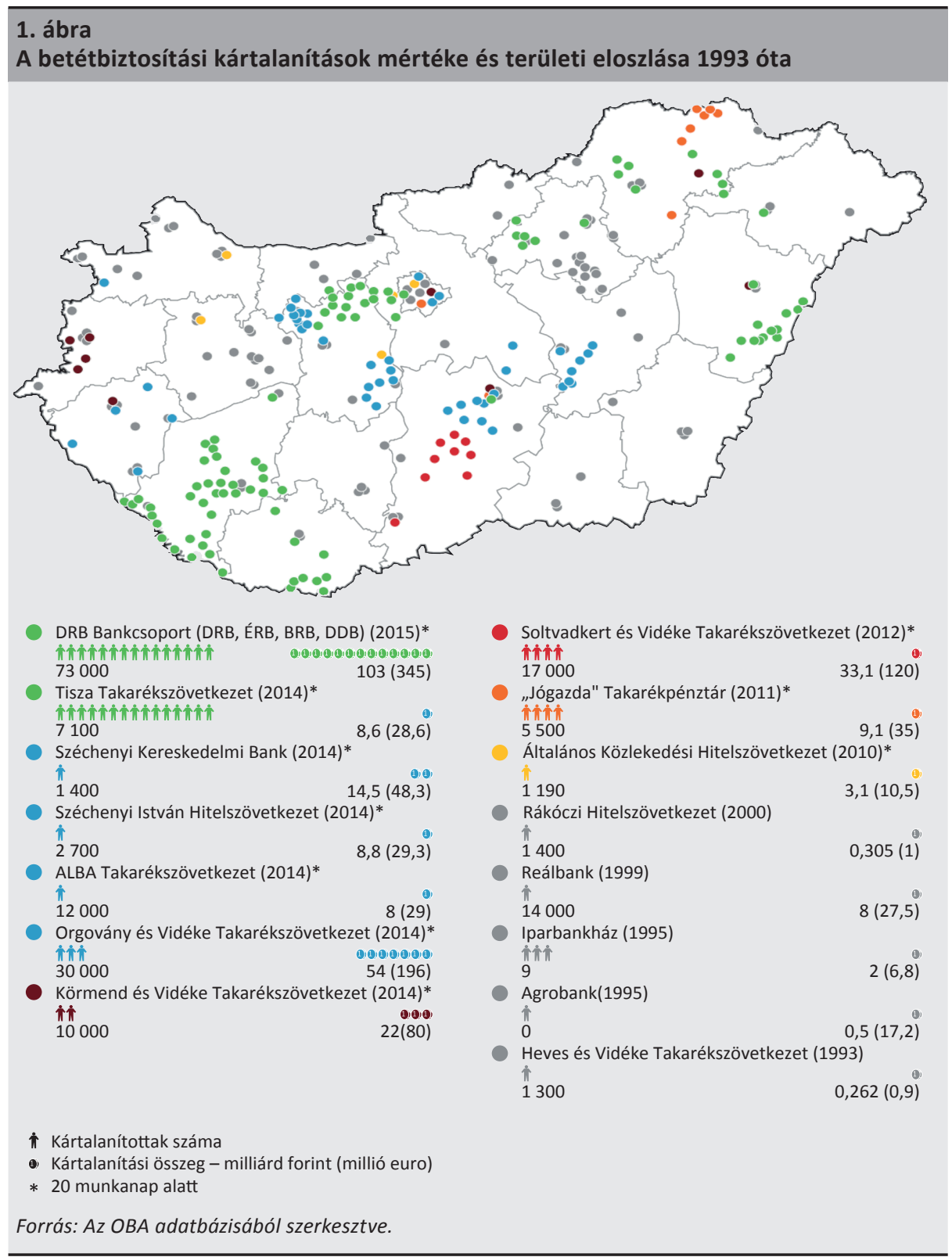


megfelelő forintösszeg (Országos Betétbiztosítási Alap 2017). ${ }^{1}$ Az OBA számításai szerint létrejötte óta (1993) közel 177 ezer ügyfél több mint 275 Mrd Ft kártalanítást kapott (nominálértéken összesítve). Az 1. ábrán a bezárt hitelintézetek fiókjainak elhelyezkedéséből jól látható, hogy a felszámolásokban a betétesek országszerte érintettek voltak.

Ahogy a térképen is szemléltetjük, az OBA megalakulása óta 18 hitelintézet került felszámolásra, melyből az utóbbi két évre 10 hitelintézet felszámolása koncentrálódott, köztük a két legnagyobb volumenű kártalanítási kényszert generáló intézménnyel (Orgovány és Vidéke Takarékszövetkezet és a négy bankból álló DRB Bankcsoport $\left.{ }^{2}\right)$.

Az OBA tartalékait a 2014-ben történt nagy volumenú kártalanítások csaknem teljesen kimerítették, és ebben a vagyoni helyzetben került sor 2015-ben a DRB Bankcsoport felszámolására, amit az OBA áthidaló jellegű jegybanki gyorshitelt követően három hónapon belül kötvénykibocsátással refinanszírozott. A kártalanítási kötelezettségek hatását az OBA fedezettségi mutatójának alakulására a 2. ábra szemlélteti. A fedezettségi mutató a betétbiztosító intézmények vagyoni helyzetét, „feltöltöttségét” méri; a betétbiztosítási alapok likvideszköz-állományát veti össze a tagintézeteknél lévő elméleti kártalanítási kötelezettséggel, egyazon időpontra

\section{2. ábra \\ Az OBA fedezettségszintjének változása a kártalanítási események hatására}

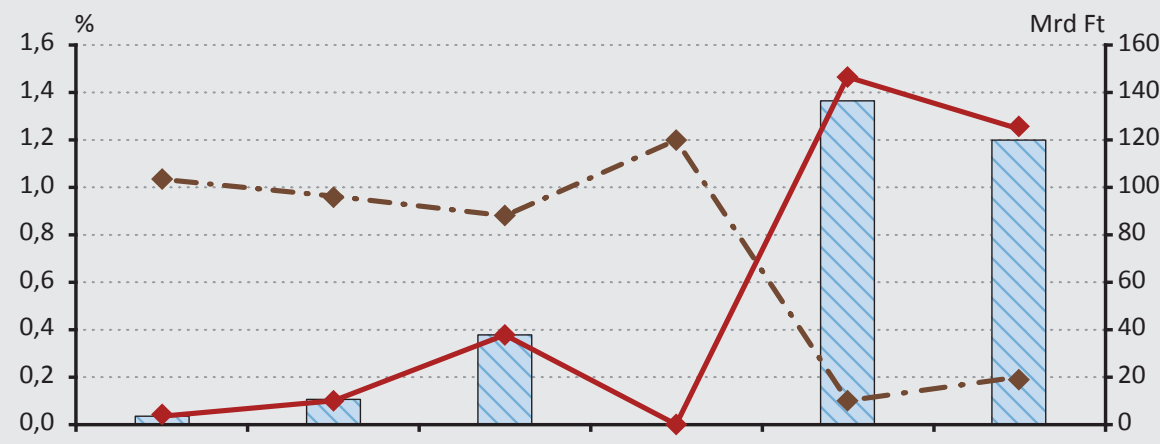

2010. dec. 31. 2011. dec. 31. 2012. dec. 31. 2013. dec. 31. 2014. dec. 31. 2015. dec. 31.

$\square$ Kifizetett kártalanítás az adott évben (Mrd Ft)

— Kifizetett kártalanítás az adott évben a teljes biztosított betétállomány arányában (\%)

- - OBA fedezettségi mutató (\%)

Forrás: Az OBA adatbázisából szerkesztve.

${ }^{1}$ Bizonyos kivételes esetekben a kifizetés felső értékhatára jelenleg további, legfeljebb 50 ezer euróval növekedhet. A 1993 előtt elhelyezett betétekre - felvételükig - továbbra is a teljes körű állami garancia vonatkozik.

${ }^{2}$ A DRB Bankcsoporthoz a BRB BUDA Regionális Bank, a DRB Dél-Dunántúli Regionális Bank, a Dél-Dunántúli Takarék Bank, valamint az ÉRB Észak-magyarországi Regionális Bank tartozik. 
vonatkozóan. A hitelintézetek felszámolása esetén a betétesek kártalanítására rendelkezésre álló vagyon alapvetően két bevételi forrásból származik: egyrészt a tagintézetek által a tárgyévben befizetett betétbiztosítási díjakból, másrészt a felhalmozott díj állampapírba való befektetésének hozambevételéből (OBA 2016:19).

Az OBA fedezettségi mutatója 2013-ig stabilan 1 százalék körül volt, 2014-re viszont 0,1 százalékra csökkent, és jelenleg is ezen a szinten áll. Ezzel az értékkel a 2015. december 31-i állapot szerint az európai betétbiztosítási alapok közül az OBA-nak az egyik legalacsonyabb a fedezettségi szintje. A betétbiztosítónak az európai uniós szabályozás ${ }^{3}$ értelmében 2024. július 3-ig el kell érnie a 0,8 százalékos fedezettségi célszintet. Ennek a célszintnek az elérése, valamint a kibocsátott kötvényekkel vállalt kötelezettségek teljesítése a jelenlegi feltöltöttséghez képest jelentős hozzájárulást igényel a tagintézményektől. Ennek oka, hogy az utóbbi két évben a teljes betétállományra vonatkozó kártalanítási kötelezettség 1,47, valamint 1,25 százalékát kellett kártalanításra fordítani. Meg kell jegyeznünk, hogy az Európai Unió által a jövőben elvárt 0,8 százalékos minimális célszint egyik évben sem fedezte volna a kártalanítási szükségletet. A fedezettségi célszint megállapításánál ezért figyelembe lehetne venni a meglévő kártalanítási tapasztalatokat is, a szabályozói minimumelvárások kiegészítéseként.

A Magyarországon felszámolt hitelintézetek betéteseinek adatbázisa hosszú idő óta első alkalommal kerül tudományos céllal elemzésre, az eredményeket jelen tanulmányban publikáljuk. A kártalanítások tapasztalatait mindeddig csak a betétesek reakcióinak vizsgálata szempontjából elemezték az OBA-ba érkezett hívások adataiból (Kiss 2015).

Jelen elemzés tapasztalatai sokrétúen hasznosíthatóak. Képet kaphatunk arról, hogy az ügyfelek jellemzően milyen összegeket helyeztek el a felszámolt intézményekben, valamint megismerhetjük a károsult betétesek korösszetételét. Ezekből következtethetünk a megtakarítási és bankolási szokásokra. A betétösszegek eloszlásának ismerete emellett felhasználható a betétbiztosítási értékhatár optimum-számításához.

\section{Adatok és módszertan}

A Magyarországon felszámolásra került hitelintézetek közül a 2014-ben és 2015ben felszámolt intézmények betéteseinek adatbázisát elemezzük, mellyel az összes (1993 óta) kártalanított betétes 77,1 százalékát és a kártalanítási összegek 79,5 százalékát fedjük le. Jelen tanulmányban a magánszemélyekhez tartozó kártalanítási összegek elemzésére fókuszálunk 188,9 Mrd Ft értékben, de kitérünk a céges kártalanítások (10,8 Mrd Ft) bemutatására is. A teljes adatbázis tartalmazza a tu-

\footnotetext{
${ }^{3}$ Az Európai Parlament és a Tanács 2014/49/EU irányelve 10. cikk (2) bekezdése.
} 
lajdonközösségek ${ }^{4}$ (0,5 Mrd Ft) kártalanítási összegeit is, melyek további kutatás tárgyát képezhetik. Az adatbázis egységei a kártalanítási összegek betétesenként és hitelintézetenkénti bontásban. Ez azt jelenti, hogy amennyiben egy betétes több hitelintézet felszámolásában is érintett volt, akkor a hozzá tartozó kártalanítás több soron szerepel. A kártalanítási összegeket az OBA a betétesek összes betétbiztosítás alá tartozó számlái, kártalanítási összeghatár alá eső betétei ${ }^{5}$ után fizette. A betétekhez tartozó kártalanítási összeg értékkészlete 0 és 100 ezer eurónak megfelelő forintösszeg. ${ }^{6}$ A statisztikákat a 0 összegű kártalanítások kiszűrésével készítjük. Ezek a kártalanításra nem szoruló ügyfelek jellemzően vagy tartozással rendelkeztek, vagy az összesített számlájuk egyenlege 0 volt. Ezen tételek kiszűrésére azért került sor, hogy az átlagos kártalanítási összeget és szórását ne torzítsák. Az adatbázis nem tartalmazza az eredeti betétösszeget, így a meg nem térített kár összegéről nincs információnk. Látni fogjuk azonban, hogy arányaiban nagyon kevés betét érte el a maximális kifizetést. A kifizetett kártalanítási összegek mellett a betétesek születési helye és ideje, valamint az állandó lakcímének irányítószáma áll rendelkezésre, melyek további kutatásra alkalmasak, a lehetőségek feltárása és az adatbázis kiegészítése folyamatban van.

A felszámolt hitelintézetek betéteseinek adatbázisát leíró statisztikai eszközökkel elemezzük a kifizetett kártalanítási összegek, valamint a betétesek életkorának dimenzióiban. Első lépésben megvizsgáljuk a kifizetett kártalanítások átlagát, szórását és eloszlását. A statisztikák eredményét intézményenként is elemezzük, hogy feltárjuk az esetleges intézményspecifikus jellemzőket. A kifizetett kártalanítási összegek eloszlásának ismeretében megfogalmazzuk, majd teszteljük azt a hipotézist, miszerint a kifizetett kártalanítási összegek extrémérték-eloszlást, azon belül is Weibull-eloszlást követnek. A kártalanított betétesek korév szerinti megoszlását a teljes magyar népesség korév szerinti megoszlásához viszonyítva elemezzük. Ehhez az OBA által rendelkezésre bocsátott adatbázist kiegészítjük a Központi Statisztikai Hivataltól gyújtött releváns demográfiai adatokkal (KSH 2015). A számításokat és a grafikonok egy részét R-programcsomag segítségével végeztük, illetve készítettük el.

\section{Kártalanítási tapasztalatok, következtetések}

\subsection{Leíró statisztikák, intézményspecifikus megállapítások}

A felszámolt hitelintézetek betéteseinek adatbázisát első lépésben a kifizetett kártalanítás átlaga és szórása tekintetében intézményenként elemezzük. A magánszemélyeknek és cégeknek kifizetett kártalanítás főátlaga 1,7 millió Ft, melyet a 3 . ábrán vízszintes szaggatott vonallal jelölünk. A főátlaghoz képest értelmezzük az egyes intézmények statisztikáit.

\footnotetext{
${ }^{4}$ Jellemzően társasházak.

${ }^{5}$ Betéti okiratok, betétszámla, folyószámla, bankszámla, fizetési számla.

${ }^{6} \mathrm{~A}$ kártalanítás időpontjában érvényes HUF/EUR árfolyamon átváltva.
} 


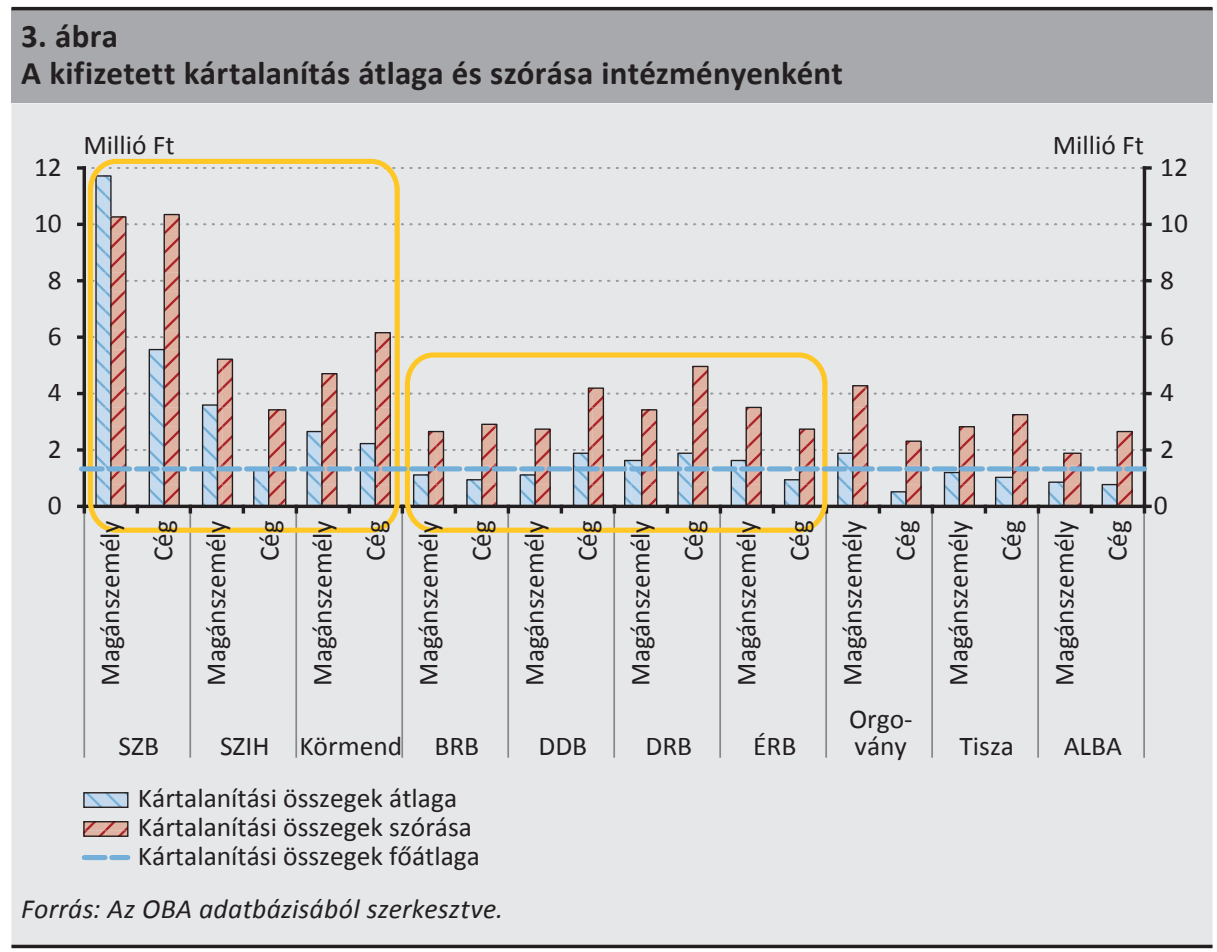

A fóátlagnál jelentősen magasabb a Széchenyi Kereskedelmi Bank (SZB), a Széchenyi István Hitelszövetkezet (SZIH) és a Körmend és Vidéke Takarékszövetkezet (Körmend) átlaga. Ennek oka lehet, hogy ez a három hitelintézet egyazon tulajdonosi kör érdekeltségébe tartozott, így a forrásgyüjtésre vonatkozó üzletpolitikát összehangolhatták. A DRB Bankcsoport négy intézménye is (BRB, DDB, DRB, ÉRB) - feltételezzük, hogy hasonló okból - egymáshoz közel álló átlagokkal rendelkezik, melyek a főátlag körül szóródnak. A maradék három hitelintézet átlagos kártalanítási összege jellemzően elmarad a fóátlagtól. Jelen kutatásnak nem célja a hitelintézetek bedőlésének okait feltárni, azonban felhívjuk a figyelmet arra, hogy a tíz felszámolt intézményből hétnél fennáll a tulajdonosi összefonódás miatti keresztfinanszírozás lehetősége. Ebből kiindulva, meglátásunk szerint az egyes intézmények tulajdonosi/érdekeltségi körének feltárása és nyomon követése felügyeleti szempontból kívánatos.

Összességében megállapítható, hogy a Széchenyi Kereskedelmi Bank statisztikája sok tekintetben eltér a többi hitelintézetétől. Az egy betétre jutó átlagos kifizetés magánszemélyek esetén több mint hétszerese (11,8 millió Ft), cégek esetén is több mint háromszorosa (5,5 millió $\mathrm{Ft}$ ) a fóátlagnak. A bank ügyfélkörében kimondottan a nagy összegú betétesek domináltak (privát banki szegmens). A relatív szórás minden intézménynél magas, 200 százalék körül alakul, a Széchenyi Kereskedelmi Bank kivételével, ahol a magánszemélyeknél 90 százalék a relativ szórás. A Széchenyi Bank statisztikája a kártalanítási összegek eloszlását tekintve is eltér a többi hitelin- 
tézetétől. Amíg az összes többi intézménynél a kártalanítási összegek eloszlásának normalitására vonatkozó feltételezés egyértelműen elutasítható7, a Széchenyi Kereskedelmi Banknál a kártalanítási összegek eloszlása közelít a normálishoz. Ennek szemléltetésére a 4. ábrát (Q-Q plot) használjuk.

\section{4. ábra \\ A Széchenyi Bank kifizetett kártalanítás eloszlásának Q-Q plot elemzése}

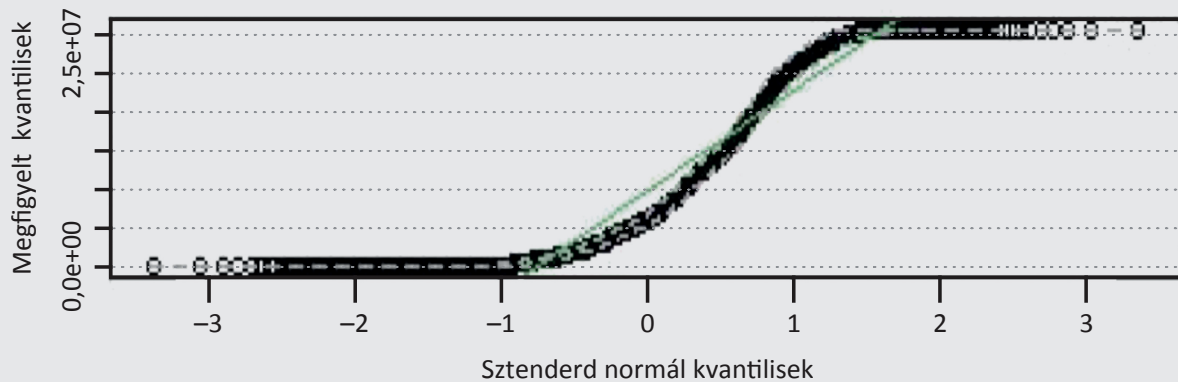

Forrás: Az OBA adatbázisából szerkesztve.

Az intézményenkénti eloszlásfüggvények alakja - a Széchenyi Bank kivételével nagyon hasonlít egymáshoz és az összes kártalanítás eloszlásához, ezért a továbbiakban a teljes sokaság eloszlásának elemzését ismertetjük.

\subsection{A kártalanítási összegek eloszlása}

A kártalanítási összegek eloszlásának megismerésével képet kaphatunk arról, hogy hányan, jellemzően milyen összegü betéteket helyeztek el a kártalanított intézményekben (5. ábra). A teljes sokaság eloszlásfüggvénye erősen balra ferdült (Módusz < Medián < Átlag), jobbra hosszan elnyúló, rásimul a vízszintes tengelyre. Kiugrás nem tapasztalható, ezért az 5. ábrán csak az eloszlásfüggvény bal szélét ábrázoljuk grafikusan, a teljes eloszlást leíró decilis értékeket feltüntetve. A leggyakrabban előforduló, tipikus kártalanítási érték (Módusz, a függvény maximumhelye) csupán 100 ezer Ft körüli. A Medián is alacsony: 368 ezer Ft, azaz a kártalanítás a betétek felénél ennél kisebb, másik felénél ennél nagyobb volt. A kártalanítási összegek átlaga betétenként 1,7 millió Ft, még a hetedik decilisnél is magasabb. Az eloszlásfüggvény alakjából tehát az látható, hogy inkább a több, kisebb összegú kártalanítás a jellemző. Ennek az lehet a magyarázata, hogy a betétbiztosítás nem csupán a lekötött betétekre vonatkozik, hanem a folyószámlákra is, melyeken - lekötés hiányában - jellemzően kisebb összegeket tartunk.

\footnotetext{
${ }^{7}$ A Kolmogorov-Smirnov-teszt alapján. Mind a kilenc esetben az átlag jelentősen magasabb volt a mediánnál, sőt nyolc esetben még a harmadik kvartilisnél is. Az eloszlás tehát mind a kilenc intézménynél a normálishoz képest balra ferdült. A magánszemélyeket és a cégeket együtt elemeztük.
} 


\section{5. ábra}

A kártalanítási összegek eloszlásfüggvényének részlete és decilis-értékei

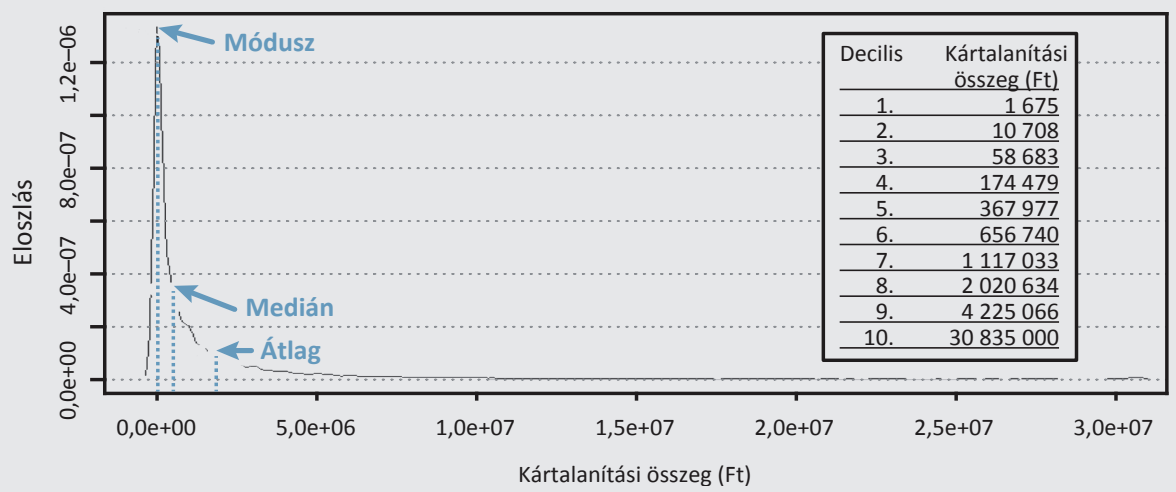

Forrás: Az OBA adatbázisából szerkesztve.

Az eloszlás decilis-értékeiből az is leolvasható, hogy ha a kártalanítás maximuma mindössze 4,2 millió Ft lett volna (9. decilis), akkor is a betétek 90 százalékát lehetett volna kártalanítani. Az eloszlás erősen balra ferdült és csúcsos ${ }^{8}$ alakjából már látható, hogy a normalitására vonatkozó feltételezés elutasítható, ezt a következtetést a Q-Q plot elemzés megerősítette.

\section{6. ábra}

\section{A normalitás tesztelése Q-Q plot elemzéssel}

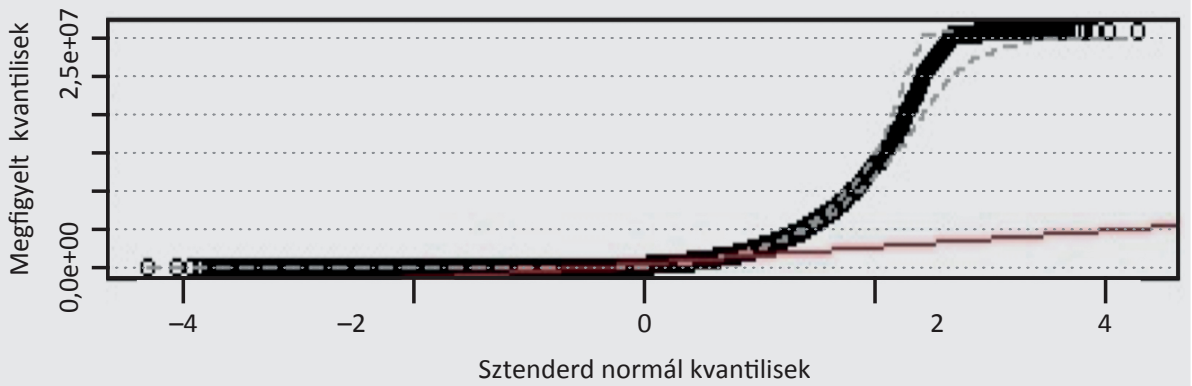

${ }^{8}$ A csúcsosságát mérő K-mutató értéke 0,175 , ami a normális eloszlást jellemző 0,263-nál csúcsosabb eloszlást ír le. 
Az eloszlásfüggvény grafikus ábrázolása alapján azt a hipotézist fogalmazzuk meg, hogy a kártalanítási összegek extrémérték-eloszlást követnek, és azon belül is Weibull-eloszlást.

A Weibull-eloszlás eloszlásfüggvénye a következő alakban írható fel, ha $x>0, k>$ $0, \lambda>0$.

$$
F(x ; k, \lambda)=1-e^{-(x / \lambda)^{k}}
$$

ahol:

k - az eloszlás alakparamétere, becsült értéke jelen esetben: $k(0,44)$

$\lambda$ - az eloszlás skálaparamétere, becsült értéke jelen esetben: $\lambda$ (696 305)

Az alakparaméter 1 alatti értéke azt mutatja, hogy az eloszlás jobbra hosszan elnyúló, azaz a kifizetések gyakorisága a magasabb összegű kártalanítások felé haladva erőteljesen csökken. Ez alapján, ha növelnék a kifizetési értékhatárt, a kártalanított betétesek száma alig nőne, viszont a kártalanítás összege jelentősen nőne.

A hipotézis teszteléséhez elvégezzük az empirikus és elméleti eloszlás összehasonlítását, melynek eredményét a 7. ábrán szemléltetjük.

\section{7. ábra}

A Weibull-eloszlás tesztelése
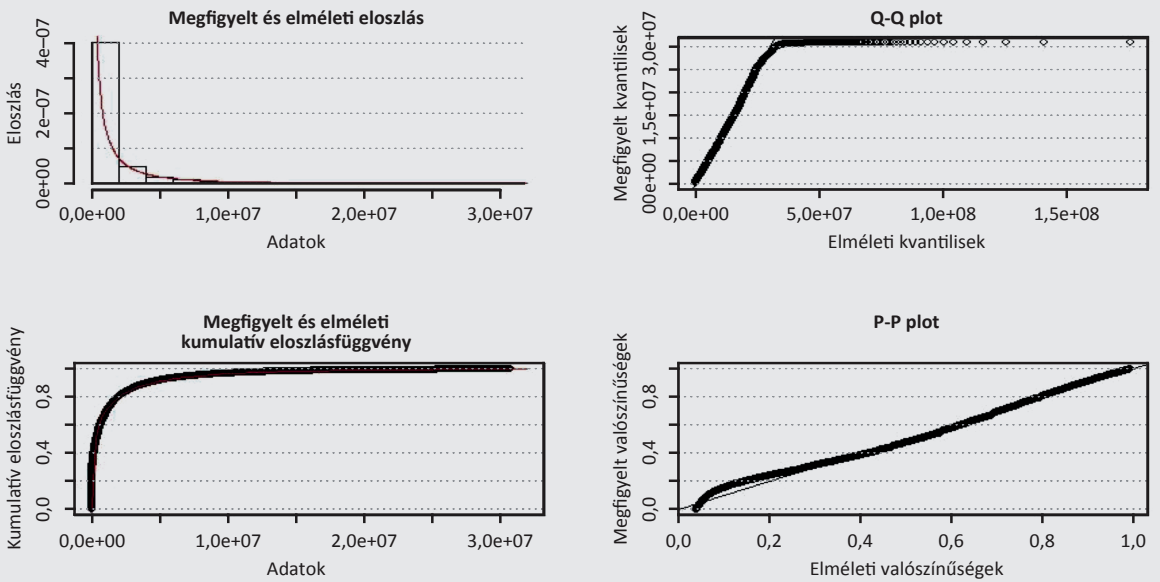

Forrás: Az OBA adatbázisából szerkesztve.

A kártalanítási összegek empirikus eloszlásából azt is látjuk, hogy már 5 millió forint felett a kártalanított betétesek száma csak kis mértékben, míg a kifizetett kártalanítások összege jelentősen nőtt. 


\subsection{Következtetések a kártalanítási összegek eloszlása alapján}

A kártalanítási összegek eloszlásának vizsgálata alapján várható az a konklúzió, miszerint betétbiztosítási szempontból a magánszemélyekre vonatkozó betétbiztosítási értékhatár optimuma Magyarországon jóval alacsonyabb szinten van, mint a jelenlegi, Európai Unió által előírt 100 ezer eurós érték. Ezt a meglátást erősíti a működő bankok betétösszegeinek eloszlásáról rendelkezésre álló információnk, miszerint Magyarországon a 2015. év végén az OBA által biztosított, magánszemélyekhez tartozó betéti számlák 97 százaléka 5 millió forint alatti biztosított összeggel rendelkezett. ${ }^{9}$ A betétbiztosítási értékhatár 5 millió forintra csökkentésével tehát 3 százalék híján az összes jelenleg biztosított magánszemély betéte garantált maradna, miközben 2426 milliárd forinttal csökkenne a biztosított betétállomány, ami a 2015. év végén a magánszemélyek összes biztosított betétállományának 42 százaléka volt. ${ }^{10}$

A biztosított betétállomány drasztikus csökkenése a betétbiztosítási rendszert tehát első ránézésre olcsóbbá tenné, hiszen jóval kevesebb tartalékot kellene képezni a biztosított betétállomány után, és ebből következik, hogy a betétbiztosítónak fizetendő díj is csökkenne. Ezzel egyidejűleg viszont modellezni kellene a biztosítási rendszerből kieső betétösszegek tulajdonosainak viselkedését. A betétbiztosítási értékhatár csökkenése ugyanis bizalomvesztést eredményezhet, ami tömeges betétkivonáshoz vezethet, veszélyeztetve ezzel a pénzügyi rendszer stabilitását. $A$ betétbiztosítási értékhatár optimumának meghatározásában a legnagyobb szerepet a fent említett tényezők játsszák. Az optimum számszerüsítésére jelen tanulmány keretei között nem teszünk kísérletet, az további kutatás tárgyát képezheti.

\subsection{A kártalanított betétesek korösszetétele}

A kártalanítási adatokat a betétesek életkorának dimenziójában is elemezzük. A kártalanított betétesek életkorának átlagát és szórását tekintve az egyes hitelintézeteknél nem találunk nagy különbségeket. Az intézményenként a betétesek átlagéletkora az 52 és a 60 év közötti intervallumban, a szórás 15 és 21 év között mozog. A magas szórást részben az magyarázza, hogy a folyószámla-termékeket és a hozzájuk kapcsolódó egyéb termékeket (folyószámlahitel, bankkártya, hitelkártya stb.) minden korosztály használja.

A kártalanított betétesek korév szerinti megoszlását a teljes magyar népesség korév szerinti megoszlásához viszonyítva elemezzük, úgy, hogy egyazon grafikonon ábrázoljuk a kártalanított betétesek életkor szerinti arányát az összes kártalanított betétesen belül, illetve a lakosság életkor szerinti arányát a teljes magyar lakosságon belül (8. ábra).

\footnotetext{
${ }^{9}$ Az OBA adatbázisából számítva

${ }^{10}$ Az OBA adatbázisából számítva
} 


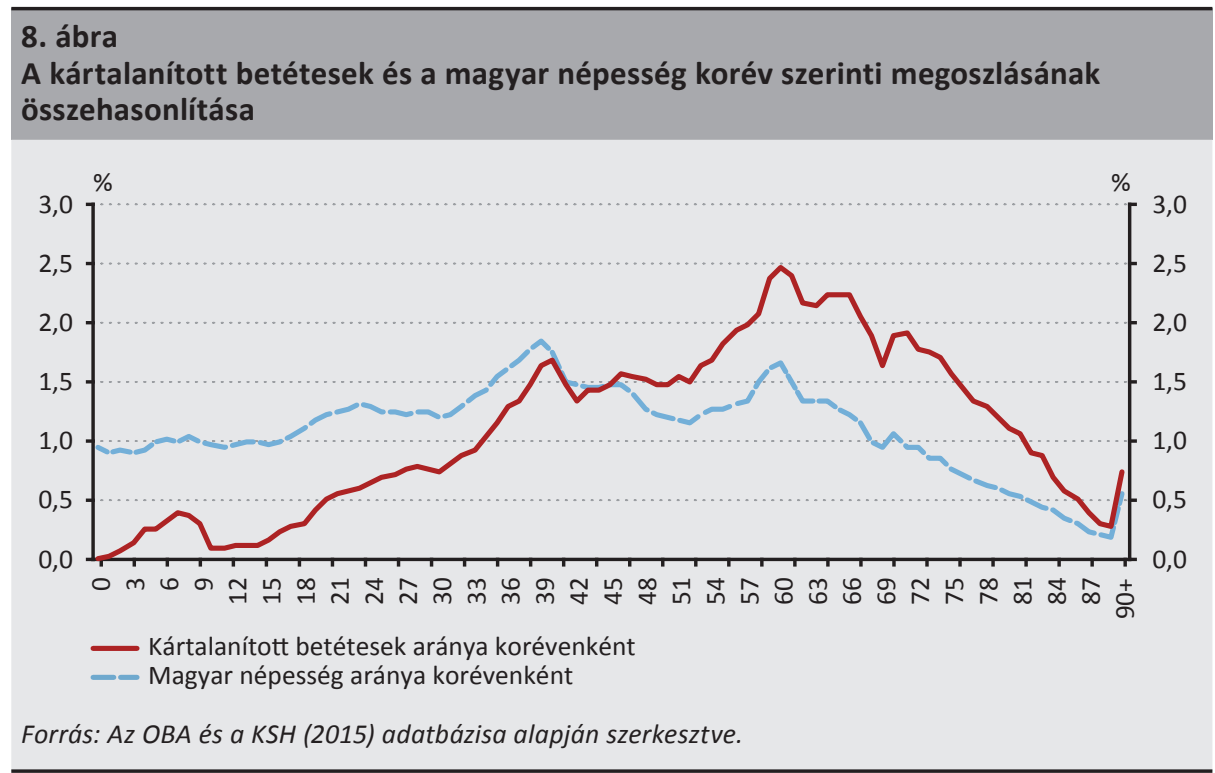

A 8. ábrán látható, hogy a két görbe csak a 40 és 45 év közötti és a 90 év feletti korosztálynál illeszkedik, a többi életkornál nem. A felszámolt hitelintézetek betétesei tehát összességében nem reprezentálják a magyar lakosság demográfiai eloszlását. Arányaiban jóval kevesebb fiatal rendelkezett betéti és számlatermékkel a felszámolt hitelintézetekben, mint amekkora a lakosságon belüli, életkor szerinti arányuk. A 40 és 45 év közötti korosztálynál a két arány megegyezik, 1,5 százalék körüli. A 45 év felettiek már arányaiban több betéttel rendelkeztek, mint amennyit a lakosságon belüli arányuk indokolt volna. A betétek életkor szerinti aránya a 60 éveseknél éri el a csúcsát (2,5 százalék), egy százalékkal meghaladva a lakossági arányukat. Idősebb kor felé haladva a kártalanított betétesek görbéje felülről közelíti a lakosságét, majd a 88 év feletti korosztálynál összeérnek. A kártalanított betétesek és a magyar lakosság életkor szerinti arányának összehasonlításában az is észrevehető, hogy a kártalanított betétesek görbéje teljesen leköveti a magyar lakosság demográfiai ugrásait („Ratkó-gyerekek” és „Ratkó-unokák”). A bankok tehát elemzésünkből következtethetnek arra, hogy portfóliójuk értékelésénél érdemes a demográfiai trendekből kiindulni.

A két görbe egymáshoz viszonyított helyzete emellett arra enged következtetni, hogy a felszámolt hitelintézetekben elhelyezett megtakarítások, számlák darabszáma Modigliani életciklus-elméletéhez (Modigliani 1986) igazodik. Modigliani életciklus-hipotézise a háztartások megtakarítási hajlandóságát vizsgáló kutatások egyik alapmodellje. Az elmélet szerint a háztartások racionális döntéseket hoznak arról, hogy mennyit akarnak fogyasztani a különböző életszakaszaikban, és ehhez a döntéshez igazítják megtakarítási magatartásukat. A fiatal háztartások megtaka- 
rítási rátája alacsony vagy negatív (hitelt vesznek fel), mivel a viszonylag alacsony jövedelemhez magas kiadások társulnak (lakásvásárlás, gyermeknevelés). A középső életszakaszban a már viszonylag magasabb jövedelemmel rendelkező háztartások bevételeik nagyobb hányadát fordítják megtakarításra, hogy felkészüljenek a nyugdíjas évekre, amikor már nem lesz jövedelmük a modell kiinduló feltételezése szerint (Modigliani 1988). További kutatás tárgyát képezheti annak vizsgálata, hogy az életkor szerinti átlagos kártalanítási összegek Modigliani életciklus-modelljét empirikusan alátámasztják-e.

\subsection{Következtetések a kártalanított betétesek korösszetétele alapján}

Összefoglalva azt tapasztaljuk a kártalanított betétesek korösszetételének vizsgálatából, hogy Modigliani életciklus-elméletének megfelelően a 40 év alattiak, köztük különösen a fiatal felnőttek és a fiatalkorúak lakossági arányukhoz képest alulreprezentáltak a betételhelyezés tekintetében. A bankok nézőpontjából ez az eredmény úgy értelmezhető, hogy a fiatal korosztályt célzó termékek fejlesztésében jelentős potenciál van. A bankoknak is érdekében áll tehát az oktatásba beépíteni a bankszámlakezeléssel kapcsolatos ismereteket.

\section{Felhasznált irodalom}

Boldizsár Anna - Koroknai Péter (2016): Nem is gondolnád, mi mindent tettek félre a magyarok (2. rész). https://www.mnb.hu/letoltes/boldizsar-anna.pdf. Letöltés ideje: 2016. november 29.

Kiss Hubert János (2015): Nem pánikoltuk túl a brókercsődöket. http://index.hu/gazdasag/ penzbeszel/2015/03/23/oba_bank_bankbetet. Letöltés ideje: 2016. december 1.

KSH (2015): Központi Statisztikai Hivatal: Népesség korév és nem szerint. http://www.ksh. hu/docs/hun/xstadat/xstadat_eves/i_wdsd009.html. Letöltés ideje: 2016. november 10.

Modigliani, F. (1986): Life cycle, individual thrift, and the wealth of nations. American Economic Review, Vol. 76 (June): 297-313.

Modigliani, F. (1988): Pénz, megtakarítás, stabilizáció. Közgazdasági és Jogi Könyvkiadó, Budapest.

OBA (2017): Országos Betétbiztosítási Alap: Betétvédelem. http://oba.hu/hu/betetvedelem. Letöltés ideje: 2017. március 29.

OBA (2016): Országos Betétbiztosítási Alap: OBA Éves jelentés 2015. Budapest, 2016. május 22., 19 o. 